\title{
Diseminasi teknologi penambahan suplemen pakan pada ikan gurami (Osphronemus gouramy) untuk peningkatan kesejahteraan petani ikan
}

\author{
Roffi Grandiosa1*, Rosidah², Pringgo Kusuma Dwi Noor Yadi Putra ${ }^{3}$ \\ 1 Universitas Padjadjaran, Bandung, Indonesia, email: roffi.grandiosa@unpad.ac.id \\ 2Universitas Padjadjaran, Bandung, Indonesia, email: rosidah@unpad.ac.id \\ 3 Universitas Padjadjaran, Bandung, Indonesia, email:pringgo.kusuma@unpad.ac.id \\ ${ }^{*}$ Koresponden penulis
}

\section{Info Artikel}

Diajukan: 2021-11-15

Diterima: 2021-12-26

Diterbitkan: 2022-01-07

Keywords:

aquaculture; gourami; feed; probiotic

Kata Kunci:

akuakultur; gurame; pakan; probiotik

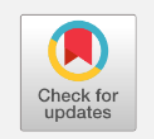

(i) (2)

Lisensi: cc-by-sa

Copyright ( 2022 Roffi Grandiosa, Rosidah, Pringgo Kusuma Dwi Noor Yadi Putra

\begin{abstract}
Aquaculture practices in the Pangandaran District highly depend on the knowledge of the farmers to support feasible aquaculture production. One of the main constraints is the knowledge of nutrition that often becomes the culprit for the low production. Kertayasa Village's aquaculture farmers are grouped in the Kawungsari Group and are well-known in Pangandaran for their Gouramy (Osphronemus gouramy). However, the knowledge of feed enrichment in regards to successful aquaculture has not been quite developed. The initiative to inform and direct farmers regarding the knowledge of feed enrichment has brought a positive result where farmers were now quite aware on the important factors of feed quality such as feed conversion ratio, effects of feed to growth and innovation in feed to support the production of fish. The method of delivering material is through presentations, training and simulations, as well as question and answer with participants which aims to find out and provide solutions to the constraints of participants in conducting data analysis in the field of cultivation. Further, knowledge on feed nutrition must be repeated, enhancing practical guide in nutrition practices. Therefore the success of aquaculture in rural areas rely on best practices knowledge to empower community development.
\end{abstract}

\section{Abstrak}

Praktek budidaya perikanan di Kabupaten Pangandaran sangat bergantung pada pengetahuan petani untuk mendukung produksi budidaya yang layak. Salah satu kendala utama adalah pengetahuan gizi yang sering menjadi biang keladi rendahnya produksi. Para pembudidaya budidaya di Desa Kertayasa yang tergabung dalam Kelompok Kawungsari cukup mapan di Pangandaran karena dikenal dengan budidaya ikan gurami (Osphronemus gouramy). Namun, pengetahuan pengayaan pakan dalam hal budidaya ikan yang sukses belum cukup berkembang. Inisiatif untuk menginformasikan dan mengarahkan petani tentang pengetahuan pengayaan pakan telah membawa hasil positif dimana petani sekarang cukup sadar akan faktor-faktor penting kualitas pakan seperti rasio konversi pakan, pengaruh pakan terhadap pertumbuhan dan inovasi pakan untuk mendukung produksi. ikan. Metode penyampaian materi dilakukan dengan presentasi, pelatihan dan simulasi, serta tanya-jawab dengan peserta yang bertujuan untuk mengetahui dan memberikan solusi atas kendala-kendala peserta dalam melakukan analisis data di bidang budidaya. Selanjutnya, pengetahuan tentang nutrisi pakan harus diberikan berulang kali dengan peningkatan panduan praktis dalam 
praktik nutrisi. Oleh karena itu keberhasilan budidaya di daerah pedesaan bergantung pada pengetahuan praktik terbaik untuk memberdayakan masyarakat berkembang.

Cara mensitasi artikel:

Grandiosa, R., Rosidah, \& Putra, P. K. D. N. Y. (2022). Diseminasi teknologi penambahan suplemen pakan pada ikan gurami (Osphronemus gouramy) untuk peningkatan kesejahteraan petani ikan. Jurnal Inovasi Hasil Pengabdian Masyarakat (JIPEMAS), 5(1), 71-79. https://doi.org/10.33474/jipemas.v5i1.13861

\section{PENDAHULUAN}

Kelompok pembudidaya ikan Kawungsari yang berada di Desa Arjasari wilayah Kecamatan Cijulang Pangandaran merupakan kelompok perikanan yang berprestasi. Adapun anggotanya adalah petani ikan yang berdomisili di desa Kertayasa, tersebar di beberapa dusun yakni Dusun Bugel, Dusun Tenjolaya dan Dusun Karangpancing. Desa Arjasari yang memiliki luas wilayah 1.355.610 Ha dan memiliki jarak yang dekat dengan lbukota Kabupaten yaitu sejauh $5 \mathrm{Km}$. Area perkolaman cukup banyak ditemui mengingat sumber air yang sangat memadai. Adapun jenis kolam ikan dibagi menjadi kolam khusus dan kolam pekarangan sebagai pelengkap rumah. Keberadaan kolam khusus ikan yang berdekatan dengan sawah sangat mendukung pendapatan rumah tangga selain sumber pendapatan lain seperti peternakan dan pertanian.

Masyarakat pembudidaya ikan di Desa Kertayasa, Kecamatan Cijulang Pangandaran saat ini menyadari bahwa tambahan penghasilan dari perikanan hanya mampu ditingkatkan bila dilakukan secara berkelompok. Dengan adanya kelompok pembudidaya tentunya akan menunjang aktivitas-aktivitas seperti penyuluhan dari Dinas Perikanan yang mampu dilaksanakan secara mikro maupun kedepannya secara makro (Koentjaraningrat, 1992). Kegiatankegiatan yang berpola tersebut dapat dilaksanakan secara berkesinambungan, sehingga merupakan suatu aktivitas-aktivitas yang terlembagakan (Suwartapradja, 2010). Sebagaimana yang terlihat di Desa Kertayasa, dimana aktivitas budidaya perikanan sudah terlembagakan dalam kelompok pembudidaya Kawungsari bahkan sudah diapresiasi oleh pemerintah melalui penghargaan Juara 3 Unit Pembenihan Rakyat bidang budidaya perikanan Kementerian Kelautan Perikanan pada tahun 2014 (KKP, 2014).

Beberapa kegiatan perikanan yang dilakukan saat ini antara lain adalah budidaya ikan nila, lele, gurame, patin, dan mina padi. Kegiatan budidaya ikan gurami masih dilakukan dan menjadi prioritas mengingat profitnya relatif lebih tinggi. Maka, pengetahuan kelompok tani di wilayah Desa Kertayasa mengenai teknik budidaya ikan gurami sudah seharusnya terus diasah. Beberapa hal yang menjadi perhatian adalah adanya kendala saat melakukan pendederan dan pembesaran ikan gurami. Pendederan ikan budidaya sangat dipengaruhi oleh pengelolaan kualitas air dan nutrisi ikan yang memadai. Menurut Ojwala et al. (2018) kondisi sanitasi perairan di kolam sangat menentukan terjadinya infeksi penyakit yang disebabkan oleh virus, bakteri, ataupun parasit terhadap ikan. Berbagai faktor fisika dan kimia seperti suhu, amonia, DO, pH, kekeruhan, dan konduktivitas memiliki pengaruh kuat terhadap kesehatan dan juga ketahanan ikan terhadap terserangnya berbagai penyakit. Petani sudah sangat memahami alur kerja dari kegiatan budidaya untuk menghasilkan ikan sehat. 
Akan tetapi, inovasi perlu untuk terus dilakukan agar dapat menunjang kegiatan budidaya ikan, sehingga masyarakat memiliki wawasan agribisnis yang lebih kuat. Oleh karena itu, kerjasama antar setiap stakeholder sangatlah dibutuhkan terhadap segala bentuk kegiatan masyarakat dengan tujuan untuk menunjang perekonomian masyarakat yang lebih maju, mandiri, dan juga kreatif (Nopriono \& Suswanta, 2019).

Salah satu kendala yang dialami pembudidaya ikan gurami adalah pertumbuhannya yang relatif lebih lambat dibandingkan ikan air tawar lainnya. Berdasarkan pengamatan, untuk menghasilkan ikan gurami jantan seberat 250 gram/ekor dan ikan gurami betina seberat 200 gram/ekor membutuhkan waktu sekitar 10-12 bulan. Menurut Nugroho et al. (2012), pertumbuhan lebih lambat bila dibandingkan dengan ikan nila yang hanya membutuhkan waktu sekitar 56 bulan. Pertumbuhan yang lambat ini disebabkan oleh beberapa faktor, diantaranya adalah kualitas benih yang kurang baik, lingkungan yang tidak mendukung, dan pemberian pakan yang tidak sesuai dengan kebutuhan ikan (Ahmad et al., 2017). Sementara itu, kegiatan budidaya yang termasuk kedalam kategori berhasil sangat ditentukan dari kualitas benih yang mencakup: kecepatan tumbuh, efisiensi pakan, ketahanan terhadap peyakit dan ketahanan terhadap lingkungan. Oleh karena itu, adanya rekayasa pada pakan merupakan salah satu faktor penting yang dapat menjadi bahan pertimbangan bagi para pembudidaya karena memiliki nilai ekonomis (Sularto et al., 2020).

Dengan penggunaan metoda pengabdian terintegrasi riset maka penulis bermaksud untuk mendiseminasikan hasil penelitian yang diadakan di lokasi tersebut dengan menambahkan kitosan pada pakan benih ikan gurami untuk membantu mempercepat pertumbuhan. Abdel-Ghany \& Salem (2020) menunjukkan bahwa kitosan dapat menjadi suplemen pakan ikan karena mampu meningkatkan fungsi kerja usus dalam menyerap nutrisi dan meningkatkan laju pertumbuhan. Selain itu, umumnya pemberian kitosan sebanyak 1-5 g dalam pakan ikan dapat meningkatkan performa dan menurunkan tingkat kematian ikan karena stress (Udo et al., 2018). Melalui kegiatan pengabdian terintegrasi riset ini, ditemukan bahwa hasil penelitian menunjukkan bahwa sebanyak $5 \mathrm{~g} / \mathrm{kg}$ pakan selama 60 hari mampu meningkatkan laju pertumbuhan, kelangsungan hidup, dan kualitas daging benih ikan gurami (O. gourami). Penambahan bobot harian ikan cukup besar yaitu sebanyak $0.70 \pm 0.03 \mathrm{~g} /$ hari dan FCR yang dihasilkan sebesar $1.45 \pm 0.07$. Saat penelitian berlangsung, petani ikan ikut membantu menyiapkan pakan, sarana dan menimbang ikan secara berkala untuk mendapatkan manfaat dan dapat melihat langsung pertumbuhan ikan yang diinginkan.

\section{METODE PELAKSANAAN}

Pelaksanaan kegiatan pengabdian dilaksanakan pada hari Rabu tanggal 13 Oktober 2021. Metode yang digunakan dalam pengabdian pada masyarakat di kelompok pembudidaya Kawungsari adalah metode pendekatan secara partisipatif. Beragamnya latar belakang pendidikan yang dimiliki oleh para peserta pengabdian menjadi dasar pemilihan metode tersebut. Perbedaan latar belakang tersebut tentu saja dapat mempengaruhi kemampuan konsentrasi 
setiap individu karena pada dasarnya setiap individu memiliki kebiasaan tersendiri dalam membekali dirinya sendiri dengan pengetahuan yang baru. Penggunaan pendekatan bertujuan agar pelaksanaan pengabdian dapat berjalan lebih efektif dan tidak membosankan (Nurman, 2015).

Metode penelitian tindakan partisipatif sebagai tujuan utama dalam merencanakan dan melakukan proses penelitian bersama dengan masyarakat. Adapun instrument untuk menggali data adalah dengan wawancara semiterstruktur. Sistem yang terintegrasi tersebut akan membawa sejumlah permasalahan atau pertanyaan pada sebuah menjadi dua perspektif, yaitu sains dan juga praktik. Oleh karena itu, dalam hal ini peneliti dan juga masyarakat akan mendapatkan manfaat dari proses penelitian yang telah dilakukan (Bergold \& Thomas, 2012). Begitu juga dengan kegiatan yang dilakukan pada kelompok pembudidaya ikan (Pokdakan) Kawungsari ini. Penelitian mengenai penambahan kitosan pada pakan ikan gurami ini dilakukan di Desa Arjasari dengan melibatkan langsung para pembudidaya dari Pokdakan Kawungsari.

Hasil dari penelitian yang telah dilakukan ini selanjutnya dipaparkan kepada pembudidaya dari Pokdakan Kawungsari dalam bentuk penyuluhan. Selain melakukan penyuluhan, pendampingan juga dilakukan ceramah dan diskusi. Sejumlah kegiatan tersebut dilakukan agar tercipta interaksi yang intensif antara peserta dengan pelaksana kegiatan. Selain itu, pendekatan secara partisipatif ini juga dilakukan dengan melakukan pengumpulan dan analisis data secara sistematis dengan tujuan mengambil tindakan untuk dapat memberikan pengetahuan praktis kepada masyarakat. Oleh karena itu, masyarakat dapat terdorong untuk melakukan aksi transformatif untuk meningkatkan kondisi menjadi lebih baik (MacDonald, 2012). Evaluasi kegiatan juga dilakukan untuk menilai pengaruh dari dilakukannya rangkaian kegiatan dengan memberikan kuesioner kepada masyarakat yang terlibat. Beberapa pertanyaan diajukan dengan jawaban berbentuk skala likert, yaitu: sangat tidak setuju, tidak setuju, biasa saja, setuju, sangat setuju.

\section{HASIL DAN PEMBAHASAN}

Kegiatan pengabdian masyarakat ini dilakukan dengan mengintegrasikan kegiatan pengabdian masyarakat yang dilakukan oleh dosen peneliti dengan kegiatan penelitian hibah riset Universitas Padjadjaran. Pelaksanaan kegiatan pengabdian dihadiri langsung oleh ketua peneliti (Roffi Grandiosa, S.Pi., MSc., PhD) serta beberapa anggota tim dari peneliti. Selain itu, dari desa Kertayasa Kabupaten Pangandaran dihadiri oleh anggota Pokdakan Kawungsari, mahasiswa program studi perikanan Universitas Padjadjaran serta perwakilan penyuluh perikanan dari Dinas Kelautan, Perikanan dan Ketahanan Pangan, Kabupaten Pangandaran. Kegiatan pengabdian berlangsung dari pukul 10.00 hingga pukul $15.30 \mathrm{WIB}$.

Pengabdian dimulai dengan melakukan pemaparan materi mengenai kegiatan budidaya ikan gurami secara umum dan juga beberapa faktor yang mempengaruhi pertumbuhan ikan gurami. 


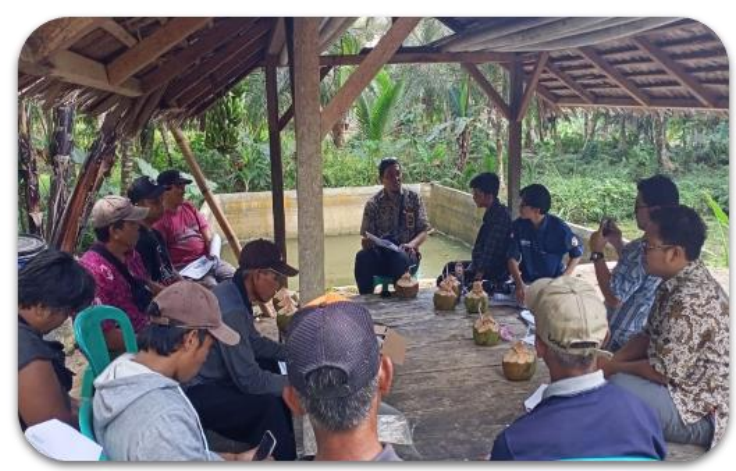

Gambar 1. Penyuluhan di kelompok pembudidaya ikan kawungsari

Selanjutnya pelatihan penambahan kitosan pada pakan ikan gurami juga dilakukan untuk memberikan wawasan dan ilmu baru yang harapannya dapat diimplementasikan oleh para pembudidaya dari Pokdakan Kawungsari. Materi pelatihan didapatkan dari hasil penelitian yang telah dilakukan dan juga disaksikan oleh para anggota Pokdakan Kawungsari.

Kegiatan pemaparan dilanjutkan dengan sesi tanya jawab dan juga diskusi bersama Pokdakan dan juga perwakilan dari penyuluh perikanan. Terdapat beberapa point penting yang dirasakan oleh para pembudidaya berdasarkan kesimpulan yang telah didapatkan pada sesi tanya jawab dan diskusi, yaitu penguasaan teknologi, pendampingan dan juga peran mahasiswa. Para pembudidaya mengakui bahwa mereka belum banyak mengetahui mengenai teknologi dan inovasi pakan yang saat ini berkembang khususnya pada budidaya ikan gurami. Masyarakat pedesaan yang pada umumnya memiliki pemahaman yang dangkal mengenai perkembangan teknologi, perlu untuk didampingi sehingga dapat mengikuti perkembangan zaman (Fikri et al., 2020). Hal tersebut dikarenakan para pembudidaya kurang memahami media untuk mencari tahu setiap perkembangan yang terus terjadi pada dunia perikanan. Sehingga pendampingan berkelanjutan yang dilakukan oleh pihak pengabdi maupun instansi terkait dalam membina kegiatan budidaya ikan gurami perlu dilakukan untuk membantu masyarakat menjadi masyarakat yang mandiri, maju, dan sejahtera (Rahmatin \& Mahagangga, 2016).

Peran peneliti dan juga instansi terkait merupakan kunci penting dalam membina kegiatan budidaya yang dilakukan oleh masyarakat. Hal tersebut untuk meminimalisir terjadinya kerugian yang dapat terjadi apabila tidak adanya pendampingan. Kegiatan pendampingan masyarakat yang dilakukan oleh instansi terkait, lembaga pendidikan dan juga lembaga penelitian merupakan suatu strategi yang dapat memberikan keberhasilan dalam program pemberdayaan masyarakat (Siswanti et al., 2016). Selain itu, peran mahasiswa dirasa begitu penting dalam masa pendampingan. Para pembudidaya merasakan bahwa tingginya peran mahasiswa berguna untuk menjangkau sekaligus membantu memperkenalkan teknologi dan juga inovasi kepada para pembudidaya di Pokdakan Kawungsari. Hal tersebut dikarenakan para pembudidaya di Pokdakan Kawungsari merasakan bahwa mahasiswa dengan 
lebih mudah dapat berkomunikasi dan melebur bersama lingkungan (Cahyono, 2019; Syahputra \& Putra, 2020).

Evaluasi kegiatan pengabdian dilakukan setelah seluruh sesi pemaparan, pelatihan dan diskusi selesai dilakukan. Hasil evaluasi didapatkan dengan menggunakan kuesioner yang diberikan dan diisi secara langsung oleh para pembudidaya pada akhir sesi. Secara umum hasil kuesioner tersebut menunjukkan bahwa para pembudidaya memiliki kesan positif yang dihasilkan. Kesan positif yang dihasilkan dapat menjadi rujukan yang disampaikan oleh para peserta kepada masyarakat mengenai info materi terkait pengabdian yang telah mereka lakukan. Hal tersebut menunjukkan bahwa selama kegiatan pengabdian berlangsung, para peserta mendapatkan pengalaman yang unik (Pribadi et al., 2020). Tabel 1. Menunjukkan hasil rekapitulasi dari kuesioner kepuasan peserta yang disajikan kepada Pokdakan Kawungsari.

Tabel 1. Rekapitulasi kuesioner kepuasan peserta

\begin{tabular}{|c|c|c|c|c|c|c|}
\hline \multirow{2}{*}{ No. } & \multirow{2}{*}{ Pernyataan } & \multicolumn{5}{|c|}{ Skala Penilaian (orang) } \\
\hline & & SS & S & $B$ & TS & STS \\
\hline 1 & $\begin{array}{l}\text { Materi yang disampaikan sesuai dengan kebutuhan } \\
\text { peserta }\end{array}$ & 10 & & & & \\
\hline 2 & $\begin{array}{l}\text { Kegiatan pengabdian dilaksanakan sesuai harapan } \\
\text { peserta }\end{array}$ & 10 & & & & \\
\hline 3 & $\begin{array}{l}\text { Cara pemateri menyajikan materi pengabdian } \\
\text { menarik }\end{array}$ & 10 & & & & \\
\hline 4 & Materi yang disajikan jelas dan mudah dipahami & 10 & & & & \\
\hline 5 & $\begin{array}{l}\text { Setiap pertanyaan dan saran yang diberikan oleh } \\
\text { peserta telah di jawab dengan baik }\end{array}$ & 10 & & & & \\
\hline 6 & $\begin{array}{l}\text { Peserta mendapatkan manfaat dari pengabdian } \\
\text { yang dilaksanakan }\end{array}$ & 10 & & & & \\
\hline 7 & $\begin{array}{l}\text { Kegiatan pengabdian meningkatkan pengetahuan } \\
\text { peserta }\end{array}$ & 10 & & & & \\
\hline 8 & $\begin{array}{l}\text { Secara umum, mitra puas terhadap kegiatan } \\
\text { pengabdian }\end{array}$ & 10 & & & & \\
\hline
\end{tabular}

Para pembudidaya yang tergabung dalam Pokdakan Kawungsari sangat setuju bahwa materi yang disampaikan sesuai dengan kebutuhan dan dapat memenuhi harapan mereka sehingga dapat memberikan manfaat untuk kedepannya. Kegiatan penyuluhan maupun pengabdian yang baik haruslah berorientasi kepada masyarakat agar hasil dari kegiatan tersebut dapat diimplementasikan oleh masyarakat dan memiliki manfaat bahkan memberikan keuntungan (Ghofirin \& Karimah, 2017; Ma'arif et al., 2016). Selain itu, metode pelaksanaan pengabdian yang dilakukan dengan menggunakan metode partisipatif ini dapat menyajikan materi pengabdian dengan jelas, menarik dan mudah dipahami. Metode partisipatif merupakan metode penyampaian yang tepat untuk menumbuhkan partisipasi masyarakat yang tinggi karena dalam prakteknya (Hudayana et al., 2019). Para pembudidaya juga sangat setuju bahwa dengan diadakannya kegiatan pengabdian ini dapat meningkatkan pengetahuan mereka. Hal tersebut sesuai dengan hasil penelitian menurut 
Ghofirin \& Karimah, 2017 bahwa kegiatan pengabdian kepada masyarat memberikan pengaruh kepada masyarakat untuk meningkatkan kemandirian, motivasi, dan juga kesejahteraan.

\section{KESIMPULAN}

Pengabdian ini menunjukkan bahwa kegiatan ini dapat meningkatkan ilmu dan wawasan para pembudidaya yang tergabung pada Pokdakan Kawungsari, Desa Kertayasa, Kecamatan Cijulang, Kabupaten Pangandaran. Penggunaan metode pendekatan secara partisipatif terbukti dapat menunjang penyampaian materi sehingga para pembudidaya dapat memahami manfaat dari penambahan kitosan pada pakan dalam kegiatan budidaya ikan gurami. Pengabdi, instansi terkait dan juga mahasiswa memiliki peran penting dalam penyampaian ilmu dan juga wawasan demi meningkatkan pengetahuan para pembudidaya. Rangkaian kegiatan pengabdian memberikan pengetahuan baru kepada masyarakat Pokdakan Kawungsari dalam hal inovasi pendederan ikan gurami melalui pencampuran kitosan pada pakan. Kegiatan pengabdian seperti ini perlu dilakukan secara berkelanjutan sebagai bentuk pendampingan terhadap para pembudidaya ikan yang berada di tengah masyarakat. Mahasiswa memiliki peran yang penting dalam melakukan pendampingan disamping dari petugas instansi maupun dosen karena memiliki kemampuan yang dinilai dapat lebih berbaur terhadap masyarakat. Berdasarkan hasil dari evaluasi kegiatan menunjukkan bahwa rangkaian kegiatan pengabdian ini dapat memberikan pemahaman baru yang dapat dimanfaatkan sesuai dengan harapan para pembudidaya yang tergabung pada Pokdakan Kawungsari.

\section{UCAPAN TERIMA KASIH}

Ucapan terima kasih kepada Universitas Padjadjaran yang telah mendanai program ini melalui skema penelitian RPLK Universitas Padjadjaran 2021 (No. 1960/UN6.3.1/PM.00/2021) yang diintegrasikan terhadap Program Pengabdian Masyarakat.

\section{DAFTAR RUJUKAN}

Abdel-Ghany, H. M., \& Salem, M. E. (2020). Effects of dietary chitosan supplementation on farmed fish; a review. Reviews in Aquaculture, 12(1), 438-452. https://doi.org/10.1111/raq.12326

Ahmad, N., Martudi, S., \& Dawami. (2017). The Effect Of Different Protein Levels On The Growth Of Gourami (Osphronemus gouramy). Jurnal Agroqua: Media Informasi Agronomi Dan Budidaya Perairan, 15(2), 5158. https://journals.unihaz.ac.id/index.php/agroqua/article/view/197

Bergold, J., \& Thomas, S. (2012). Participatory Research Methods: A Methodological Approach in Motion. Historical Social Research / Historische Sozialforschung, 37(4 (142)), 191-222. https://doi.org/10.2307/41756482

Cahyono, H. (2019). Peran Mahasiswa di Masyarakat. De Banten-Bode: Jurnal Pengabdian Masyarakat Setiabudhi, 1(1), 32-43. https://stkipsetiabudhi.e-journal.id/DeBode/article/view/34 
Fikri, R., Amrillah, M. F., \& Mulianto, B. (2020). Critical Discourse Analysis of Technology-Based Rural Government System in Bengkalis Riau. Journal of Local Government Issues, 3(1). https://doi.org/10.22219/logos.v3i1.10929

Ghofirin, M., \& Karimah, Y. I. (2017). Pengabdian Pada Masyarakat Pondok Pesantren Qomaruddin Desa Bungah Gresik Kewirausahaan Santri. Community Development Journal, 1(2), 56-61. https://doi.org/https://doi.org/10.33086/cdj.v1i2.340

Hudayana, B., Kutanegara, P. M., Setiadi, S., Indiyanto, A., Fauzanafi, Z., Nugraheni, M. D. F., Sushartami, W., \& Yusuf, M. (2019). Participatory Rural Appraisal (PRA) untuk Pengembangan Desa Wisata di Pedukuhan Pucung, Desa Wukirsari, Bantul. Bakti Budaya, 2(2), 3. https://doi.org/10.22146/bb.50890

KKP, K. K. dan P. (2014). Keputusan Menteri Kelautan dan Perikanan Republik Indonesia Nomor 75 Tahun 2014 tentang Penerima Penghargaan Adibakti Mina Bahari Tahun 2014. KKP.

Koentjaraningrat. (1992). Beberapa Pokok Antropologi Sosial. Dian Rakyat.

Ma'arif, R., Zulkarnain, ., Nugroho, T., \& Sulistiono, . (2016). Pemberdayaan Masyarakat Nelayan melalui Pengembangan Perikanan Tangkap di Desa Majakerta, Indramayu, Jawa Barat. Agrokreatif Jurnal IImiah Pengabdian Kepada Masyarakat, 2(1), 17-24. https://doi.org/10.29244/agrokreatif.2.1.17-24

MacDonald, C. (2012). Understanding Participatory Action Research: A Qualitative Research Methodology Option. Canadian Journal of Action Research, 13(2),

34-50.

https://doi.org/https://doi.org/10.33524/cjar.v13i2.37

Nopriono, \& Suswanta. (2019). Pemberdayaan Masyarakat dalam Perspektif Collaborative Governance (Studi Kasus Kelompok Budidaya Ikan Mina Bayu Lestari dan Dinas Kelautan dan Periakanan Kabupaten kulon Progo). Jurnal Pemerintahan Dan Kebijakan (JPK), 1(1), 21-36. https://doi.org/10.18196/jpk.v1i1.7799

Nugroho, E., Nafiqoh, N., \& Gustiano, R. (2012). Produktivitas Beberapa Varietas Ikan Gurame (Osphronemus gouramy). Prosiding Forum Inovasi

Teknologi Akuakultur, 1095-1101.

Nurman. (2015). Strategi Pembangunan Daerah. RajaGrafindo Persada.

Ojwala, R. A., Otachi, E. O., \& Kitaka, N. K. (2018). Effect of water quality on the parasite assemblages infecting Nile tilapia in selected fish farms in Nakuru County, Kenya. Parasitology Research, 117(11), 3459-3471. https://doi.org/10.1007/s00436-018-6042-0

Pribadi, M. A., Yoedtadi, M. G., Utami, B., \& Siswoko, K. H. (2020). Pengabdian

Kepada Masyarakat Sebagai Cara Memperkenalkan Prodi IImu Komunikasi Untar Kepada Siswa Siswi Di SDS Sumbangsih. Jurnal Bakti Masyarakat Indonesia, 2(2), 62-70. https://doi.org/10.24912/jbmi.v2i2.7226

Rahmatin, L. S., \& Mahagangga, I. G. A. O. (2016). Wisata Museum Berbasis Edutainment di Jawa Timur Park Kota Batu, Jawa Timur. JURNAL 
DESTINASI

PARIWISATA,

$4(2)$

$169-174$.

https://doi.org/10.24843/JDEPAR.2016.v04.i02.p30

Siswanti, A. D., Muadi, S., \& Chawa, A. F. (2016). Peran Pendampingan dalam

Program Pemberdayaan Masyarakat (Studi pada Program

Pendampingan Keluarga Balita Gizi Buruk di Kecamatan Semampir Kota

Surabaya). Wacana Journal of Social and Humanity Studies, 19(3), 128-

137. https://wacana.ub.ac.id/index.php/wacana/article/view/417

Sularto, Febrianti, R., \& Listiyowati, N. (2020). Estimasi Profit Usaha Budidaya Beberapa Persilangan Ikan Gurami (Osphronemus goramy). Media Akuakultur, 15(1),

47-52.

https://doi.org/http://dx.doi.org/10.15578/ma.15.1.2020.47-52

Suwartapradja, O. S. (2010). Pranata Sosial dalam Pertanian: Studi tentang Pengetahuan Lokal pada Masyarakat Petani di Jawa Barat. Sosiohumaniora, 12(1), 86-98.

https://doi.org/10.24198/sosiohumaniora.v12i1.5442

Syahputra, A., \& Putra, H. R. (2020). Persepsi Masyarakat Terhadap Kegiatan Kuliah Pengabdian Masyarakat (KPM). At-Tanzir: Jurnal Ilmiah Prodi Komunikasi Penyiaran https://doi.org/10.47498/tanzir.v11i1.349 Islam, 11(1), 1. I. U., Etukudo, U., \& Anwana, U.-I. U. (2018). Effects of Chitosan and Chitosan Nanoparticles on Water Quality, Growth performance, Survival Rate and Meat Quality of the African Catfish, Clarias Gariepinus. Nanoscience, 1(1), 12. https://doi.org/10.31058/j.nano.2018.11002 